\title{
Numerical Modelling and Geotechnical Monitoring of an Anchor Wall System for a Deep Excavation in Lima Conglomerate
}

\author{
German D. Matos Paucar, MSc ${ }^{1}$, Jose W. Gutierrez Lazares, MSc ${ }^{2}$ \\ ${ }^{1}$ Universidad Nacional de Ingenieria, Peru, dmatosp@uni.edu.pe, \\ 2 Universidad Nacional de Ingenieria, Peru, wgutierrez@uni.edu.pe
}

The city of Lima is located in an area where the soil is mainly composed of coarse granular material known as Lima conglomerate. It is characterized by having good geomechanical properties from a civil engineering point of view. However, there has always been some difficulty in obtaining the necessary parameters, basically because of the lack of laboratory equipment.

On the other hand, the city has played a key role in the country's economic growth over the last two decades, where many new and modern buildings have taken place which in turn include the construction of several basements as part of them. In this regard, the Anchor Wall system (Sort of a combination of Diaphragm wall and Soil Nailing) has shown a good performance during the excavation phase, taking advantage of the quite good geotechnical characteristics of this alluvial gravel deposit.

This research aims at determining the soil parameter in an indirect way, it means that the real lateral displacements, obtained by geotechnical monitoring in a given project, will be compared with that output data obtained by a previous numerical simulation. It is worth mentioning that the first input data used in the computational stage was based on a proper collection of information about the predominant soil in Lima.

The results show coherence between the horizontal displacements seen in-situ with that obtained by The Finite Element Method (FEM); thus contributing to the geomechanical characterization of Lima Conglomerate. Last but not least, the safety and efficiency of this technology were proven once again during the project monitoring.

Keywords-Anchor Wall System, Lima Conglomerate, Finite Element Method, Inclinometer, Coarse granular soils.

\section{INTRODUCTION}

It has been many years since a large number of building structures started constructing in the Peruvian capital, most them imply the building of several basements for parking spaces, so it is no wonder that many excavations took place in the city, moreover when it comes to the urban area.

It can be said that the Anchor Wall system involves constructing a perimetral underground wall, which in turn consists of panels that are constructed in situ as the soil is removed. Then, the soil pressure on their retained side is balanced by post-tensioning anchors (See Fig. 1). This technology is only possible thanks to the nature of Lima conglomerate, enabling us to construct quickly and safety until pit bottom level is completed.

As for the design stage, it is hard for engineers to define the geotechnical parameters in order to compute the active earth pressure against retaining walls, which is why the compilation of both previous and similar experiences is necessary.

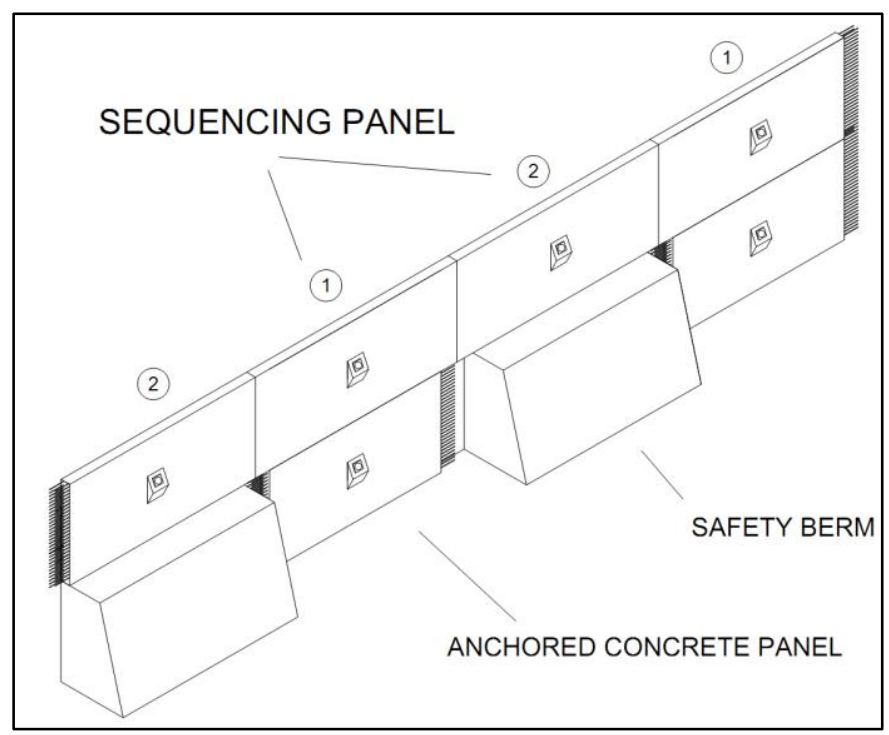

Fig. 1 Scheme of the constructive process. (Pilotes Terratest Peru, 2013)

A further point is about the many developed methodologies to estimate the earth pressure. To illustrate we can point out that Empirical Methods are the most widely used methodology, and are used for embedded wall design and, in order to obtain the design anchor forces for multi-anchored walls. Such methods are based on the stress redistribution diagram obtained from laboratory experience. Similar guidance and empirical graphs exist in German Recommendations on Excavations: EAB [1]

Another point is one that focuses precisely on the calculation of the lateral displacement of the retaining wall, because of the lack of elastic parameters obtained properly. To exemplify, it is usual to take parameters from the bibliography as well as from the Chilean experience where a similar soil in Santiago de Chile is characterized through a Large Scale Triaxial Testing as we can see in the Reference [2].

Considering the facts outlined above, the purpose of this research is both simulating and monitoring a certain project, then verify the input data in an unconventional way (Measuring in situ movements), and subsequently use this set of geotechnical parameters as suggestions for future works with similar characteristics. 


\section{II. GEOTECHNICAL CHARACTERIZATION OF LIMA CONGLOMERATE}

The great characteristics of the typical soil in Lima cannot be better illustrated as in the Fig. 2, where the height of the almost vertical excavation is around 6 meters without any type of retaining structure which lead us to expect high parameters in comparison with other typical granular soils. So, let us recall some former studies.

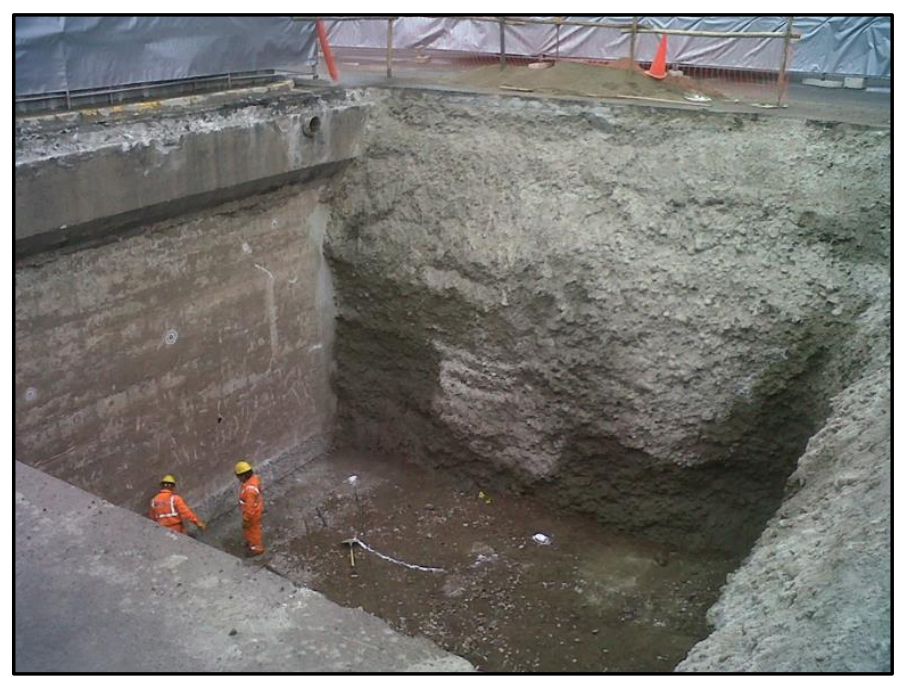

Fig. 2 View of the typical Gravel in Lima. Height of excavation is approximately 6 meters (Pilotes Terratest Peru, 2012)

According to the reference [3], most of Lima area is covered by alluvial gravels that are found at few meter depth. The same authors found Shear wave velocities $\left(\mathrm{V}_{s}\right)$ of the order of $800 \mathrm{~m} / \mathrm{s}$ (See Fig. 3) Which corresponds to a Very dense soil and Soft Rock for the International Building Code [4].

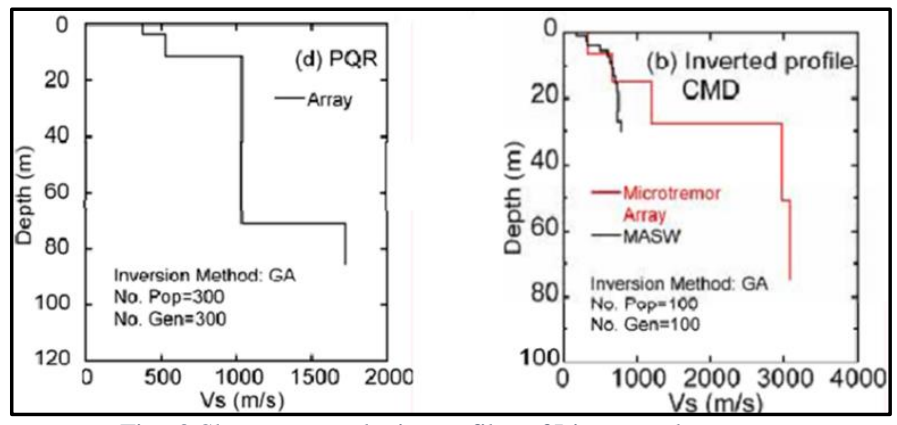

Fig. 3 Shear-wave velocity profiles of Lima conglomerate

Similarly, the reference [5] summarized results (Shear Strength Parameters) from many In-situ Direct Shear Test carried out for different projects in Lima over the time, concluding that the ranges of values for Cohesion (C) and Friction Angle $(\phi)$ are the following $20-40 \mathrm{KPa}$ and $40-55^{\circ}$, respectively. Obviously, such values can vary as the depth increases.

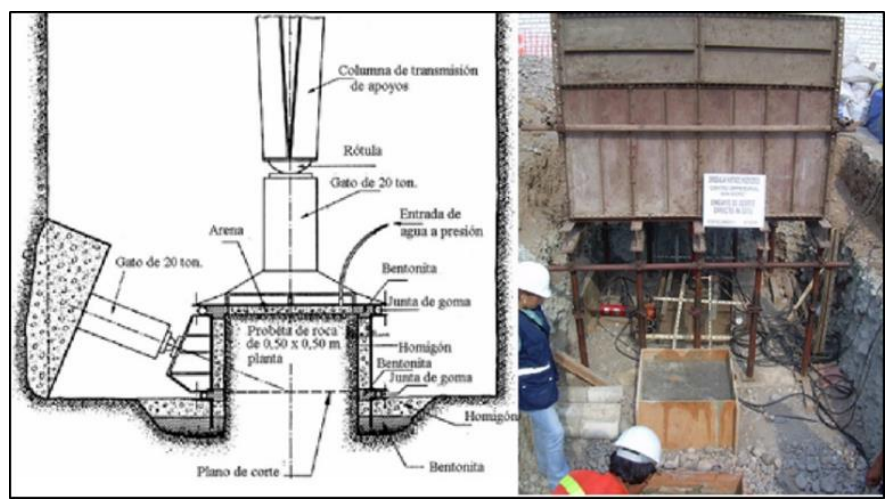

Fig. 4 Scheme of an In-Situ Direct Shear Test

\section{PROJECT OVERVIEW}

The foundation pit is located in San Isidro district, which is located in the south of the city center of Lima, Peru. The building was designed intending to be a Multi-family residential. In addition, it is included the construction of five basements (Around 16.00 meters) and that is why the Anchor Wall system was meant to retain the soil during the excavation stage (See Fig. 5).

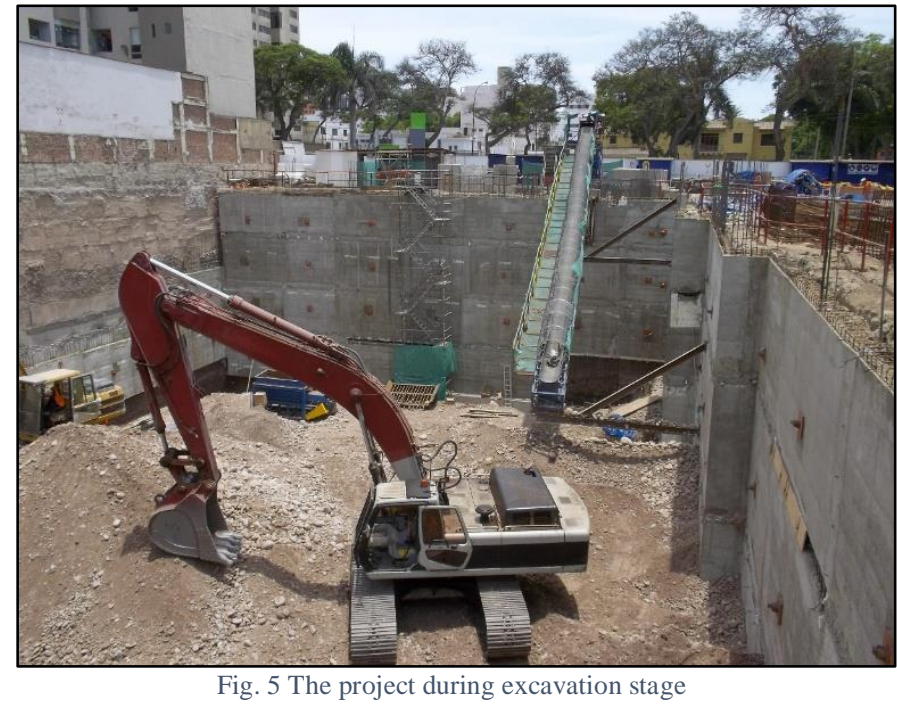

\section{A. Geotechnical Investigations}

The subsurface conditions and soil properties at the site were obtained from the geotechnical investigation and laboratory tests, summarized in the TABLE I. The site generally featured Poorly Graded Gravel (GP). Note that strength parameters were based on the experience gained over the last years, but not for any test performed. 
TABLE I

FOUNDATION SOIL LAYERS

\begin{tabular}{|c|c|c|c|c|c|}
\hline \multicolumn{2}{|c|}{ Depth } & \multirow{2}{*}{$\begin{array}{c}\text { Soil } \\
\text { (USCS) }\end{array}$} & \multirow{2}{*}{$\begin{array}{c}\text { Unit } \\
\text { Weight } \\
\left(\mathrm{KN} / \mathrm{m}^{3}\right)\end{array}$} & \multirow{2}{*}{$\begin{array}{c}\text { Friction } \\
\text { Angle }\end{array}$} & \multirow{2}{*}{$\begin{array}{l}\text { Cohesion } \\
\left(\mathrm{KN} / \mathrm{m}^{2}\right)\end{array}$} \\
\hline From & To & & & & \\
\hline 0.00 & 1.20 & $\mathrm{Pt}$ & 19 & 20 & 5 \\
\hline 1.20 & 4.00 & GP & 21 & 38 & 20 \\
\hline 4.00 & 8.00 & GP & 22 & 40 & 30 \\
\hline 8.00 & 20.00 & GP-GM & 22 & 42 & 40 \\
\hline
\end{tabular}

\section{B. Characteristics of the Wall Anchored System}

Moving on to the specific part which will be the subject of this research, let us take the equivalent of three panels located on one of the axis (See Fig. 6). those wall panels will be stabilized by applying of post-tensing anchors on their external surface. Likewise, The TABLE II details the dimensions of every element that form the anchors.

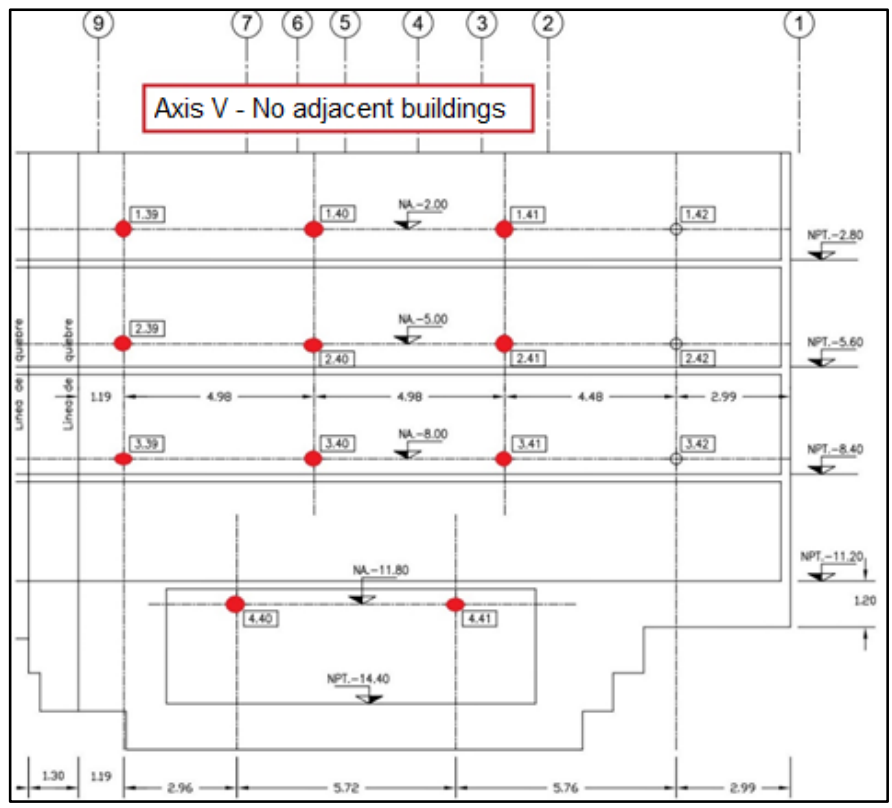

Fig. 6 Front view of the area stabilized by post-tensing anchors.

TABLE II

TECHNICAL SPECIFICATIONS OF THE ANCHORS

\begin{tabular}{|c|c|c|c|c|c|c|}
\hline \multirow{2}{*}{ Level } & \multirow{2}{*}{ Depth } & \multirow{2}{*}{ Quantity } & $\mathrm{e}_{\mathrm{h}}$ & $\mathrm{L}_{\mathrm{B}}$ & $\mathrm{L}_{\mathrm{F}}$ & Load \\
\cline { 4 - 7 } & & $(\mathrm{m})$ & $(\mathrm{m})$ & $(\mathrm{m})$ & $(\mathrm{KN})$ \\
\hline 1 & -2.5 & 3 & 5.0 & 3.5 & 7.5 & 480 \\
\hline 2 & -6.0 & 3 & 5.0 & 3.5 & 6.3 & 550 \\
\hline 3 & -9.5 & 3 & 5.0 & 3.5 & 5.5 & 550 \\
\hline 4 & -13.0 & 2 & 5.3 & 3.5 & 5.5 & 580 \\
\hline
\end{tabular}

Where:

$\mathrm{e}_{\mathrm{h}} \quad$ : Horizontal spacing

$\mathrm{L}_{\mathrm{B}} \quad$ : Bond Length

$\mathrm{L}_{\mathrm{F}} \quad$ : Free Length

\section{GEOTECHNICAL MODELISATION}

This stage design aims to define the mechanical characterization as well as the geometric model of the different materials that form the whole body, trying to reflect what happens in the reality at the maximum possible. All those data will be part of the input data for a subsequent numerical simulation by using ABAQUS code in order to estimate the change of stresses and strains state taking place in the earth structure under different construction stages. Nevertheless, we have to emphasize that good results will depend on both correct choice of parameters and a correct definition of boundary conditions.

\section{A. Constitutive Models}

As we know, soils are not linearly elastic and perfectly plastic for the entire range of loading, rather soils are complex materials, showing non-linear, anisotropic and time-dependent behavior when are subjected to stress. Conversely, reinforced concrete features an almost defined behavior, besides, the range of deformations are expected to be in the elastic regime. The TABLE III provides information on each Constitutive Model for each material and type of analysis.

TABLE III

SUMMARY OF CONSTITUTIVE MODELS USED IN THIS WORK

\begin{tabular}{|c|c|c|c|}
\hline $\begin{array}{c}\text { Constitutive } \\
\text { Model }\end{array}$ & Material & $\begin{array}{c}\text { Application } \\
\text { Case }\end{array}$ & $\begin{array}{c}\text { Dependent } \\
\text { Parameters }\end{array}$ \\
\hline $\begin{array}{c}\text { Linear } \\
\text { Elasticity }\end{array}$ & $\begin{array}{c}\text { Rock and } \\
\text { Concrete }\end{array}$ & Initial Stress & $\boldsymbol{D}(E, v)$ \\
\hline $\begin{array}{c}\text { Perfect } \\
\text { plasticity }\end{array}$ & Concrete & Slope Stability & $\boldsymbol{D}\left(E, v, \sigma_{y}\right)$ \\
\hline Mohr-Coulomb & Soil & Slope Stability & $\boldsymbol{D}(E, v, \Psi, \emptyset, C)$ \\
\hline
\end{tabular}

Where:

E : Young modulus

$v \quad: \quad$ Poisson Modulus

$\sigma_{y} \quad$ Yield strength

$\Psi \quad$ : Angle of Dilatancy

\section{B. Material Properties}

For practical reasons, we considered just one soil layer in the whole body analyzed. Otherwise, a greater number of variables would become necessary. And then again its soil parameters assumed were mainly grounded on the following:

- The geotechnical investigations mentioned before

- Previous studies in the city and detailed in the reference [3], and [5].

- Comparable experiences as that described in the reference [2].

- In the cases where coarse material, the dilatancy angle has been deduced from a simple relationship recommended by the reference [6]: $\Psi=\emptyset^{\prime}-30$

The TABLE IV and TABLE $\mathrm{V}$ show the mechanical properties for the soil and the concrete, respectively.

TABLE IV

SOIL PROPERTIES USED IN ABAQUS CODE

\begin{tabular}{|c|c|c|c|c|c|c|}
\hline Material & $\begin{array}{c}\boldsymbol{\gamma}_{\text {dry }} \\
\left(K N / m^{3}\right)\end{array}$ & $\begin{array}{c}\boldsymbol{\emptyset}^{\prime} \\
\left(^{\circ}\right)\end{array}$ & $\begin{array}{c}\boldsymbol{C} \\
(K P a)\end{array}$ & $\begin{array}{c}\boldsymbol{E} \\
(M P a)\end{array}$ & $\begin{array}{c}\boldsymbol{v} \\
(-)\end{array}$ & $\begin{array}{c}\boldsymbol{\Psi} \\
\left(^{\circ}\right)\end{array}$ \\
\hline Gravel & 20 & 40 & 30 & 300 & 0.25 & 30 \\
\hline
\end{tabular}

TABLE V

CONCRETE PROPERTIES USED IN ABAQUS CODE

\begin{tabular}{|c|c|c|c|c|c|}
\hline Material & $\begin{array}{c}\text { Width } \\
(m)\end{array}$ & $\begin{array}{c}\boldsymbol{\gamma} \\
\left(K N / m^{3}\right)\end{array}$ & $\begin{array}{c}\boldsymbol{\sigma}_{\boldsymbol{y}} \\
(M P a)\end{array}$ & $\begin{array}{c}\boldsymbol{E} \\
(G P a)\end{array}$ & $\begin{array}{c}\boldsymbol{v} \\
(-)\end{array}$ \\
\hline Concrete & 0.30 & 24 & 28 & 20 & 0.18 \\
\hline
\end{tabular}




\section{Geometry}

A series of different geometries were performed, being the most stable that one which considered 18438 three-dimensional solid elements (types-hexahedra). As might be supposed, the elements are finer near to the area of our interest (The side of the wall). The Fig. 7 describes the whole body, including forces acting on itself.

Furthermore, vertical displacement at the lateral surface boundaries is defined as null. Likewise, both vertical and horizontal displacements at the bottom of the geometry are supposed to be impeded.

- Lateral surface: $U_{x}=0, U_{y}=0$ and $U_{z} \neq 0$

- Bottom surface: $U_{x}=0, U_{y}=0$ and $U_{z}=0$

It is noticeable that the soil mass is subjected to a volume force (gravity force) as well as a surface load on the bottom part equivalent to $10 \mathrm{KN} / \mathrm{m}^{2}$ (Dead load) as is suggested in German Recommendations on Excavations: EAB [1]

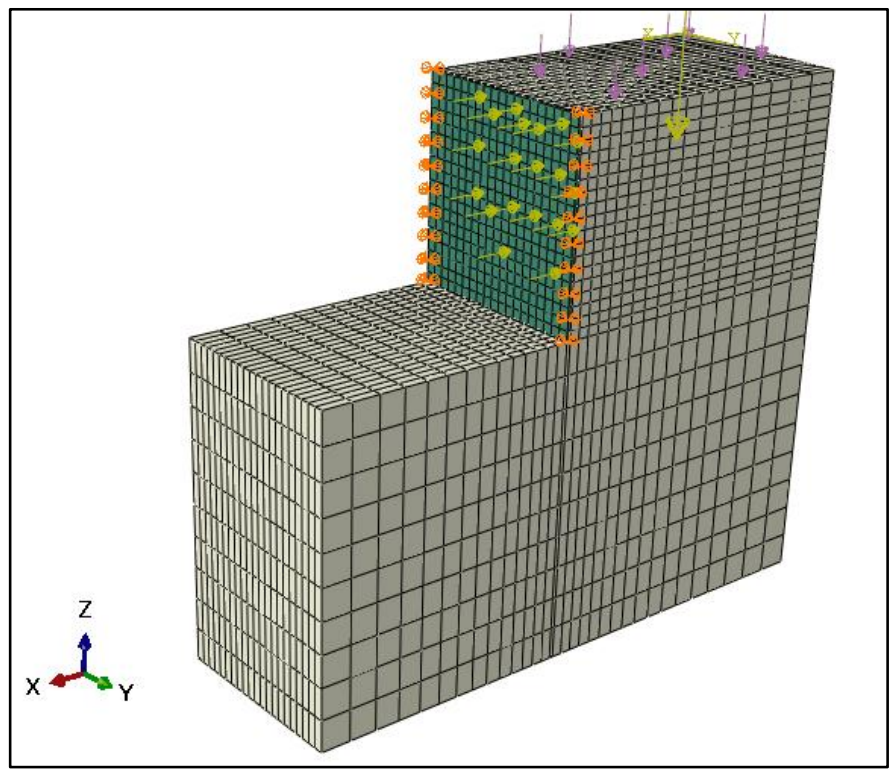

Fig. 7 Final geometric Representation of the model

\section{Construction Process}

The present methodology consists in simulating sequentially each layer is removed during the excavation. Therefore, this strategy of simulation allows the model to imitate the real sequence of construction of this structure. The Fig. 8 describes the sequential decrement of each layer, from where we can note the following:

- The height chosen for every decrement is 3.5 meters and those are represented in odd numbers.

- The even numbers represent the application of loads (Nodal forces) on the wall, simulating the anchors that take place immediately after the excavation.

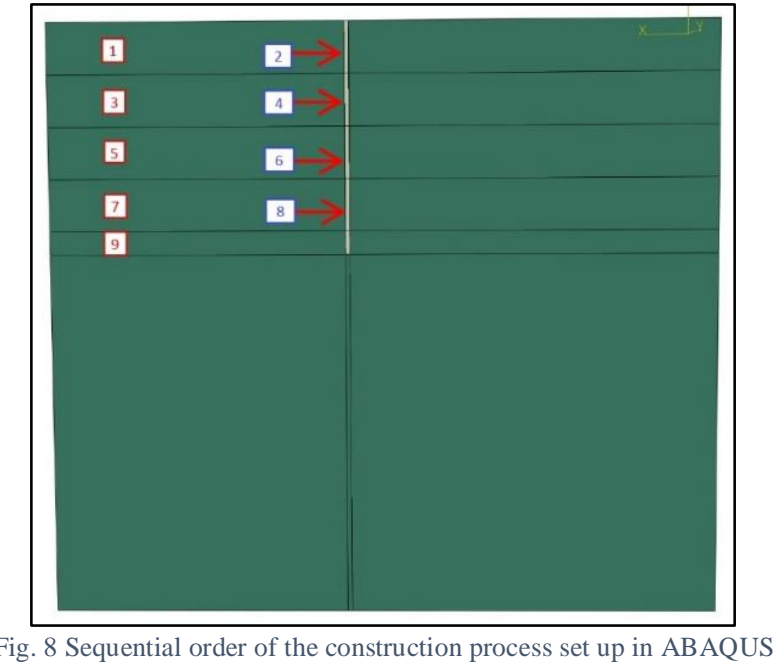

\section{E. Analysis of the Output Data}

The Fig. 9 illustrates the results (Deformed mesh) of the model under all considerations mentioned above. Additionally, it is important to recall that the diaphragm will move as a rigid body and will force the walls to move together, which bring us to the next step: Take a cross section to build up a displacement curve: Depth vs Lateral Displacement (See Fig. 10), where the most striking point to note is that the maximum lateral displacement is $7 \mathrm{~mm}$, located in the central part of the wall.

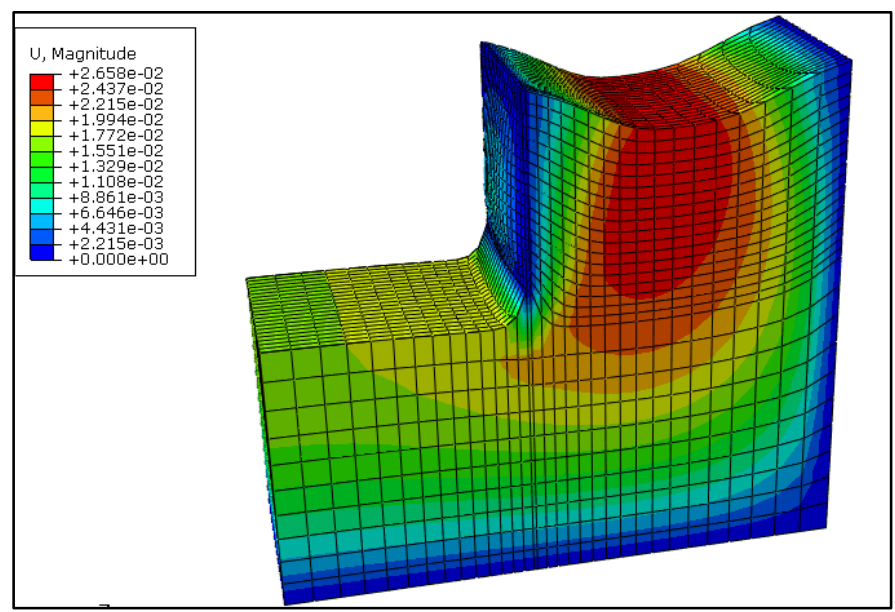

Fig. 9 Deformed mesh of total displacements. Scale x100 


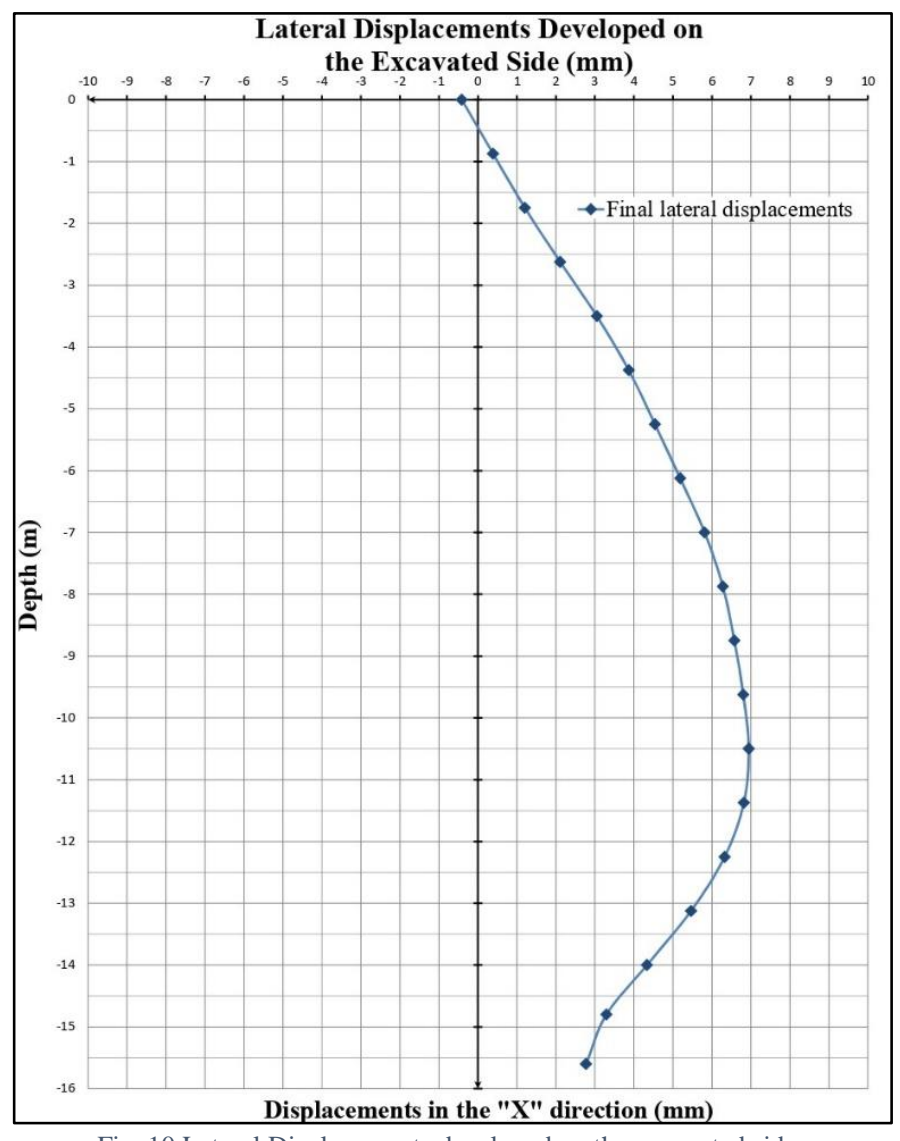

Fig. 10 Lateral Displacements developed on the excavated side

\section{GEOTECHNICAL INSTRUMENTATION FOR MONITORING FIELD PERFORMANCE: INCLINOMETERS}

Previous to any work in the project, two inclinometer pipe (Labeled as "B01" and "B02") were installed, exactly behind the analyzed panel walls, with a view to monitoring the lateral displacements while the soil removal is performed. It is worth mentioning that these elements have an embedded part in the soil below dredge line, the length of which is named penetration.

The period for the measurements depended on the works of the foundation pit. Therefore, each measure was carried out immediately upon an important step was done, such as: Excavation, Building of the wall, Application of loads, or even an extraordinary event happens.

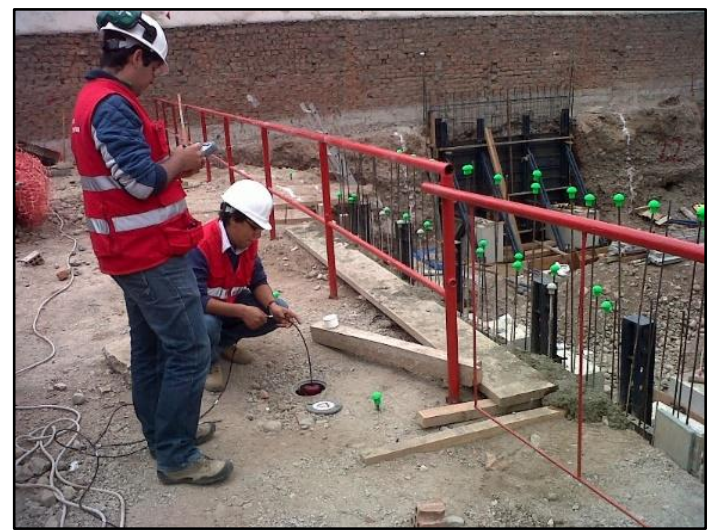

Fig. 11 Field measurements during excavation stage.

Final curves of lateral displacement of the diaphragm wall for measuring point "B01" and "B02" at depth of $20 \mathrm{~m}$ are shown in Fig. 12 and Fig. 13. The lateral displacement of the diaphragm wall overall decrease with the increasing of excavation depth. Both graphs display a maximum displacement of $6.1 \mathrm{~mm}$ which occurs on the top of the wall.

Let us compute the shear deformation, defined as $\delta_{h}=$ $h / H$, where " $h$ " is the maximum horizontal displacement and " $H$ " the height of the excavation. Hence: $\delta_{h}=0.39 / 1000$, which is below the maximum allowed according to the reference [7], where the value of $1 / 1000$ is the maximum limit for this type of structures.

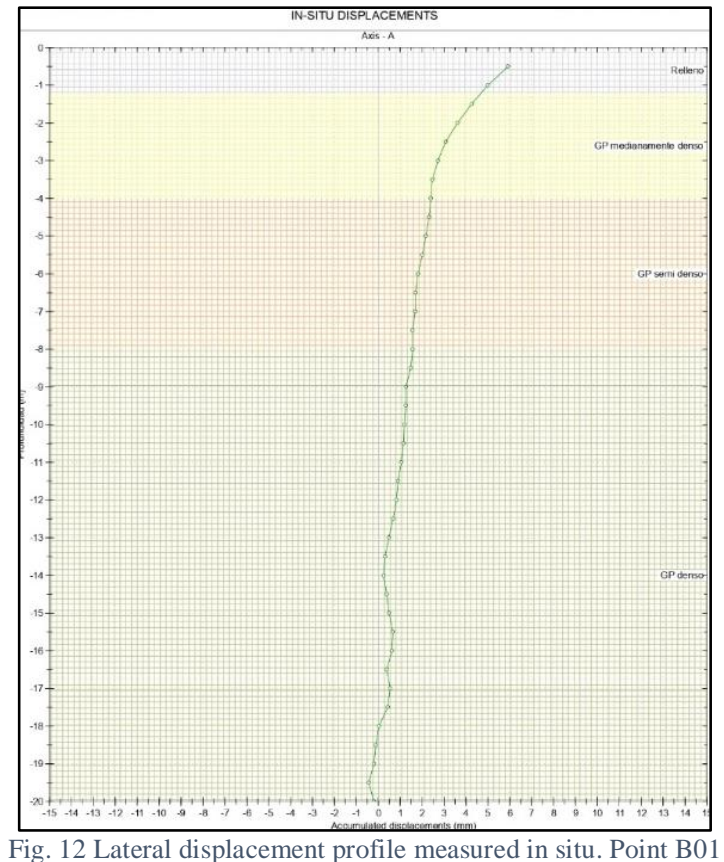




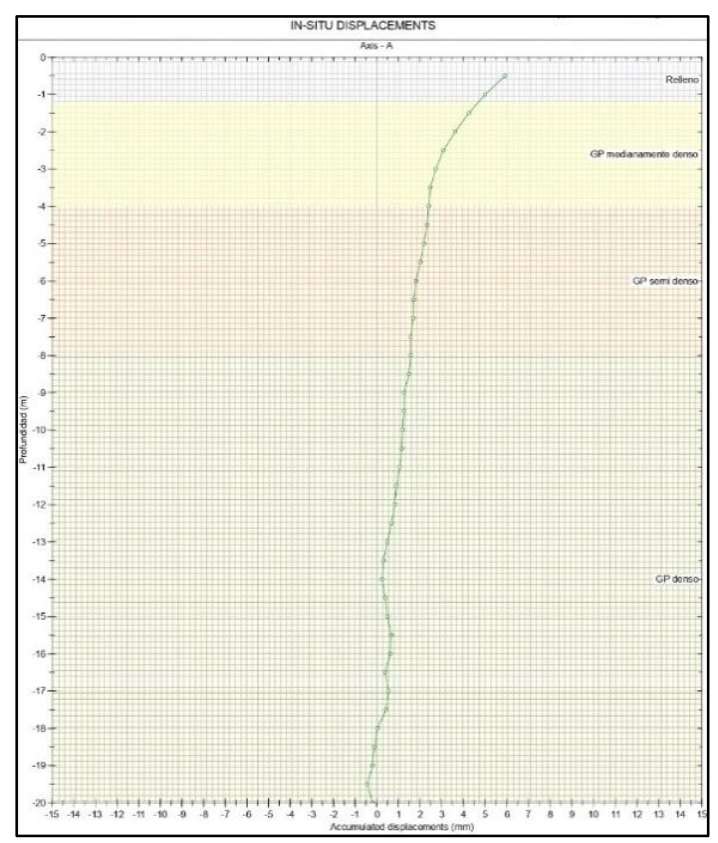

Fig. 13 Lateral displacement profile measured in situ. Point B02

\section{CONCLUSIONS}

As it can be see, the shear deformation $\left(\delta_{h}\right)$ is smaller than the maximum allowed, which is also related to a correct execution of the constructive process. It was verified during all the period of monitoring; thus reducing potential foundation settlement in the adjacent buildings. In few words, the performance of this technology has been proven quantitatively.

This research also demonstrates that, the design of this retaining structure, by using either Equilibrium Limit Analysis or Empirical Methods, has been oversized, basically because the smaller parameters considered. In other words, the greater the calculated forces are, the higher sizes of the every element will be.

The similarity between both Lateral displacements graphs, it means those curves obtained by numerical simulation and by In-situ measurement, bears out the shear strength parameters that we used as the input data: $\varnothing=40^{\circ} ; C=30 \mathrm{KPa}$.

Finally, the elastic parameters used for the gravel that were taken from both the literature review and the results of the gravel of Santiago de Chile (By using Large-scale Triaxial Testing) are consist with those measured on site. Therefore, the following values are suggested for future projects that will take place in Lima metropolitan area: $\mathrm{E}=300 \mathrm{MPa} ; \mathrm{v}=0.25$.

\section{VII.ACKNOWLEDGMENTS}

Research Institute of the Civil Engineering Faculty at the Universidad Nacional de Ingenieria (IIFIC) as well as the company Pilotes Terratest Peru for the financial support and sharing their work experience.

\section{REFERENCES}

[1] German Society for Geotechnics, Recomendations on Excavations (EAB), 2nd ed., Berlin: Ernst \& Sohn, 2008.

[2] R. Verdugo y K. Hoz, «Caracterización Geomecánica de Suelos Granulares Gruesos,» Revista Internacional de Desastres Naturales, Accidentes e infrestructura Civil, 2006.

[3] D. Calderon, T. Sekiguchi, Z. Aguilar, F. Lazares and S. Nakai, "Dynamic characteristics of the surface soils in Lima, Perú," in 8th International Conference in Urban Earthquake Engineering., Tokyo, 2011.

[4] T. L. Patterson, Illustrated 2009 Building Code Handbook, McGrawHill, 2010.

[5] S. Sánchez Rodríguez, J. M. Rodríguez Ortiz, J. D. López Valero, . C. Laina Gómez and Á. Jiménez Morales, "Caracterización de Suelos Granulares Gruesos. El caso de la Grava de Lima," Reconocimiento, tratamiento y mejora del terreno: $10^{\circ}$ Simposio Nacional de Ingeniería Geotécnica, pp. 305-312, 19, 20 y 21 Octubre 2016.

[6] S. Helwany, Applied soil mechanics with ABAQUS applications, John Wiley \& Sons, 2007.

[7] P. J. Sabatini, D. G. Pass y R. C. Bachus, GEOTECHNICAL ENGINEERING CIRCULAR NO. 4: Ground Anchors and Anchored Systems (FHWA-IF-99-015), Washington: Federal Highway Administration, 1999, p. 281.

[8] ABAQUS, “6.14 Documentation," Dassault Systemes Simulia Corporation, vol. 651, 2014.

[9] CISMID, "Estudio de Vulnerabilidad y Riesgo Sísmico en 42 distritos de Lima y Callao," Lima, 2004.

[10] M. Calvello and R. Finno, "Selecting Parameters to Optimize In Model Calibration by Inverse Analysis," Computers and Geotechnics, pp. 410424, 2004.

[11] K. Terzaghi, "Erdbaumechanik auf bodenphysikalischer grundlage," 1925.

[12] E. Santoyo Villa y J. Segovia Pacheco, «Muros Milan,» de Manual de construcción geotécnica, parte I, Sociedad mexicana de mecánica de suelos, 2002, pp. 57-203.

[13] L. F. Raygada Rojas, "Análisis de la Estabilidad y Deformaciones en el Acantilado de la Costa Verde," UNIVERSIDAD NACIONAL DE INGENIERIA, Lima, 2011.

[14] D. M. Potts and L. Zdravkovic, Finite Element Analysis In Geotechnical Engineering: Application, vol. 2, T. Telford, Ed., 2001.

[15] A. Martinez, "Conglomerado de Lima Metropolitana en Cimentaciones," in Conferencia Internacional de Ingeniería Sísmica, Lima, 2007.

[16] K. H. De la Hoz Alvarez, «Estimación de los parámetros de resistencia al corte en suelos granulares gruesos,» Universidad de Chile, Santiago de Chile, 2007.

[17] M. Braja, Principles of Foundation Engineering, Sacramento: California State University, 1999.

[18] J. E. Alva Hurtado, Diseño de Cimentaciones, 1ra Edicion ed., Lima: Fondo Editorial ICG, 2011.

[19] Sociedad Mexicana de Mecanica de Suelos, Manual de Construcción Geotécnica Tomo I, Ciudad de Mexico: Noriega Editores, 2007. 